\title{
Effect of extrusion cooking on physicochemical properties of tuna meat-based extrudates
}

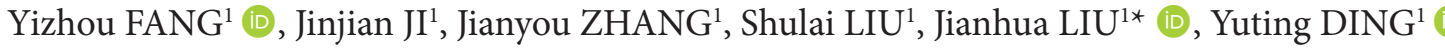

\begin{abstract}
Effect of extrusion cooking using different corn starch contents on the physicochemical properties (expansion ratio, bulk density, color, hardness, protein in vitro digestibility, crude protein content, thermal properties and microstructure) of tuna meat-based extrudates was investigated. The results showed that the increased corn starch content led to darker, greener, yellower and lower crude protein content of extrudates, but no significant difference was observed in expansion ratio, bulk density and hardness. The lowest protein in vitro digestibility of $82.83 \pm 0.39 \%$ appeared when the corn starch content was $20 \mathrm{wt} \%$. The results of DSC revealed that tuna meat with corn starch content of $30 \mathrm{wt} \%$ and $20 \mathrm{wt} \%$ had the highest and lowest denaturation temperature of $99.4^{\circ} \mathrm{C}$ and $81.9^{\circ} \mathrm{C}$, respectively. The results of SEM indicated that the extrudate with $30 \mathrm{wt} \% \mathrm{corn}$ starch content possessed the more integrated and distinct muscle fibers. Besides, the acceptability of the extrudate with $30 \mathrm{wt} \%$ corn starch content was significant better than others $(p<0.05)$. These results revealed that the tuna meat-based extrudates using $30 \mathrm{wt} \%$ of corn starch exhibited desirable physicochemical properties.
\end{abstract}

Keywords: extrusion cooking; tuna; corn starch; physicochemical properties; extrudate.

Practical Application: Tuna meat-based extrudates with $30 \mathrm{wt} \%$ corn starch have the best physicochemical properties.

\section{Introduction}

Extrusion is a food processing technique with the characteristics of high temperature and short time (De Cruz et al., 2015), which is one of the most important processing techniques applied in the development of food products (Tiwari \& Jha, 2017; Masatcioglu et al., 2014; Moscicki \& van Zuilichem, 2011). It combines several unit operations including mixing, cooking, kneading, shearing, shaping and forming (Stojceska et al., 2009). The short residence time should reduce the side reactions, such as degradation of bioactive compounds (Hirth et al., 2014). Therefore, extrusion cooking is an increasingly technology used for producing snack foods and breakfast cereals.

Extruded foods are composed mainly of cereals, starches, and/or vegetable proteins. Numerous reports showed that starch-based materials are ideal for extrusion processing (Moad, 2011; Yu et al., 2012), because the major role of these ingredients is to form the structure, texture, mouth feel and many other characteristics desired for specific finished products (Anton et al., 2009; Li et al., 2014).

Tuna, an important commodity of marine fish, is mainly used for canned and frozen products. However, a considerable part of tuna such as red meat and tail are not used, but just be a waste of environment (Suseno, 2015). It is estimated that ten percent of total fish are underutilized because of the undesirable features, including small size, dark color, strong flavor, unacceptable textural properties, and the presence of toxic substances. Utilization of low-value fishes is of great importance in developing countries. However, due to the undesirable features mentioned above, the underutilized fishes are mainly discarded rather than consumed (Tumuluru et al., 2013). Extrusion cooking will improve the texture and other physical properties of underutilized fishes and make them suitable for human consumption (Singh et al., 2014). Varieties of products with mince as raw material can be made by extrusion (Lakshmi Devi et al., 2013). Several studies have reported the successful incorporation of fish flesh or fish powder into starch-based materials by extrusion processes to produce nutritious extrudates, which could be acceptable by consumers (Samuelsen et al., 2014; Samuelsen et al., 2013; Shaviklo et al., 2011). However, the data available on tuna meat with incorporation of corn starch extrudates is limited.

In the present study, tuna meat mixed with corn starch of different contents $(20 \%, 25 \%, 30 \%, 35 \%$ and $40 \%$, w/w) was subjected to extrusion cooking processing. The experimental range of corn starch contents was determined by preliminary experiments, which showed that the extrudates with corn starch contents lower than $20 \mathrm{wt} \%$ was too hard to bite, but higher than $40 \mathrm{wt} \%$ would lead to poor formability. The aim of this study was to produce the extrudates possessed the better physical and chemical properties, with the underutilized tuna fish protein by extrusion technology, meanwhile avoiding the waste of resources. 


\section{Materials and methods}

\subsection{Materials}

Corn starch was obtained from Hengren Trade \& Industry Co., Ltd., Shandong, China. Frozen tuna (Katsuwonus pelamis) meat was stored at $-20^{\circ} \mathrm{C}$ and supported by Today's Food Co., Ltd, Ningbo, China.

\subsection{Experimental design and conditions}

The twin-screw extruder (Syslg32-II, Jinan Saibainuo Technology Development Co. Ltd, China) was used. All variables and parameters were kept constant except corn starch contents in this study. The moisture content of raw materials was $30 \%$, and the extrusion cooking parameters were as follows: barrel temperature $180{ }^{\circ} \mathrm{C}$, screw speed $250 \mathrm{rpm}$ (revolutions per minute), and feeder speed $30 \mathrm{rpm}$.

\subsection{Preparation of extrudates}

The frozen tuna meat was thawed at room temperature in the dark, and spread evenly before dried at $60{ }^{\circ} \mathrm{C}$ to control the moisture content of $36 \%$. Then it was mixed with corn starch with different contents $(20 \%, 25 \%, 30 \%, 35 \%$ and $40 \%$, w/w). After that, the mixtures were adjusted the moisture content to $30 \%$ by adding water and stored at $4{ }^{\circ} \mathrm{C}$ for $12 \mathrm{~h}$ before extrusion cooking processing. The extrudates were cooled to room temperature and then tested. The process flow chart of extrudates preparation was shown in Figure 1.

\subsection{Expansion ratio}

Sectional expansion, the ratio of diameter of the extrudates and the diameter of die ( $4 \mathrm{~mm}$ ), was used to express the expansion of extrudate (Ding et al., 2006). The expansion ratio values were obtained from 10 samples for each extrudate.

\subsection{Bulk density}

Bulk density was determined from the volume displacement method caused by the extrudates which had been previously weighed and then covered with sea sand. The volume of decrease was obtained when removing the extrudates. Measurements were made on ten randomly chosen pieces of extrudate $(2.5 \mathrm{~cm}$ long) from each run. Bulk density was calculated using the following equation:

Bulk density $(\mathrm{g} / \mathrm{mL})=$ mass of extrudate $(\mathrm{g}) /$ volume of decrease $(\mathrm{mL})$.

\subsection{Color}

The color of the extrudates was assessed using a Hunter-Labcolorimeter (Optical Sensor, Hunter Associates Laboratory Inc., Reston VA, USA). In the Hunter-Lab colorimeter, the color of a sample was denoted by the three dimensions $\left(L^{\star}, a^{\star}\right.$ and $\left.b^{\star}\right)$. The $L^{\star}$ value gave a measure of the lightness of the product from 100 for perfect white to zero for black, as the eye would evaluate it. The redness/greenness and yellowness/blueness were denoted by $a^{*}$ and $b^{*}$ values (Altan et al., 2008), respectively. Ten samples were used for each extrudate.

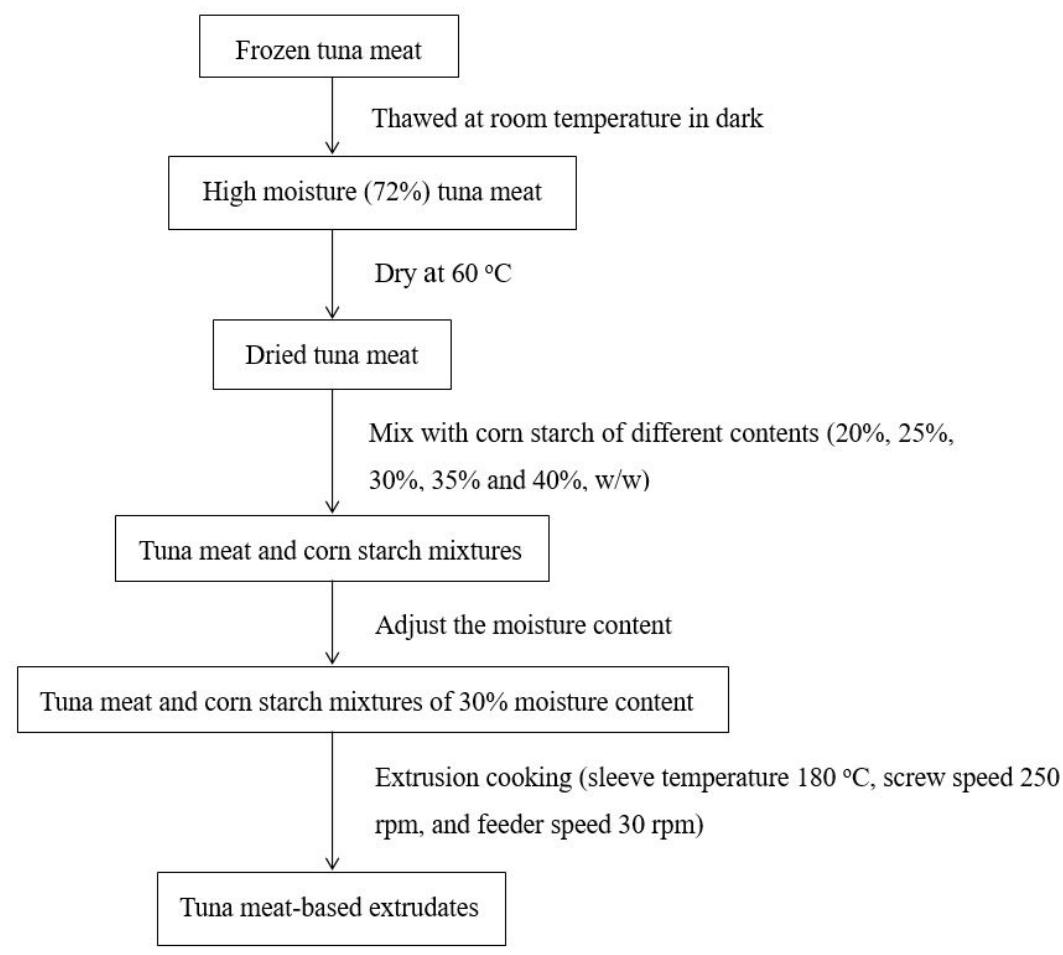

Figure 1. Process flow chart of preparation of tuna meat-based extrudates. 


\subsection{Hardness}

The texture characteristics of the extrudate were measured using a Stable Micro System TA-XT Plus texture analyser (UK) fitted with cylinder probe. Cross head speed was $1.00 \mathrm{~mm} / \mathrm{s}$. The samples were punctured by the probe to a distance of $6 \mathrm{~mm}$, corresponding to approximately $40-60 \%$ of the diameter of the extrudates. All sample sizes were $50 \mathrm{~mm}$ in length and diameters between 10.8-14.4 $\mathrm{mm}$.

\subsection{Protein In Vitro Digestibility (PIVD)}

The PIVD of the extrudates was determined by the modified method (Monsoor \& Yusuf, 2002). Extrudate (1.5 g) was suspended in $113 \mathrm{~mL}(0.1 \mathrm{~N}) \mathrm{HCl}$ solution containing $15 \mathrm{mg}$ of pepsin. The suspension was incubated for $3 \mathrm{~h}$ at $37^{\circ} \mathrm{C}$ and then neutralized with $0.2 \mathrm{~N} \mathrm{NaOH}$ to adjust the $\mathrm{pH}$ to 7.5-8.0. Phosphate $(56 \mathrm{~mL}, \mathrm{pH} 7.4)$ containing $30 \mathrm{mg}$ of pancreatin, $7.5 \mathrm{mM} \mathrm{CaCl}_{2}$ and $0.01 \% \mathrm{NaN}_{3}$ was added to the suspension. The mixture was then further incubated for $24 \mathrm{~h}$ at $37^{\circ} \mathrm{C}$ for digestion to occur. Enzyme blanks were prepared under the same conditions without extrudate samples. The undigested protein was precipitated by adding 30\% trichloroacetic acid (TCA) solution and separated by ashless filter paper (Whatman no. 4). The amount of undigested protein was measured by the Kjeldahl method $(\mathrm{N} \times 6.25)$. PIVD was calculated using the following equation:

PIVD $(\%)=[1$-Undigested protein/Total protein (in 1.5 g extrudate) $] \times 100 \%$

\subsection{Crude protein content}

Crude protein content was determined from the crude nitrogen content of the sample determined by the Kjedahl method $(\mathrm{N} \times 6.25)$.

\subsection{Differential Scanning Calorimetry (DSC)}

The DSC of extrudates was determined by the modified method (He et al., 2013). Thermal measurements were carried out using a differential scanning calorimeter (DSC-1, Mettler Toledo, Switzerland). The raw material should be freeze-dried before DSC test. Approximately $3 \mathrm{mg}$ protein powders were carefully weighed into an aluminium pan and a sealed empty aluminium pan was used as the reference. The run was conducted in the temperature range $0-100{ }^{\circ} \mathrm{C}$ in a nitrogen stream (flow rate of $20 \mathrm{~mL} / \mathrm{min}$, heating rate $5^{\circ} \mathrm{C} / \mathrm{min}$ ). The peak temperature (Tp) and heat flow were determined.

\subsection{Scanning Electron Microscope (SEM)}

The DXS-X2 scanning electron microscope (Nanjing, China) was adopted to observe the internal structure and particle distribution of extrudates. The test condition was as follows: instruct name S-4700, magnification 800, accelerating voltage 15000 Volt, emission current $9000 \mathrm{nA}$, working distance $15100 \mu \mathrm{m}$, micron marker 50000, specimen bias 0, scan speed slow 3, calibration scan speed 7, lens mode analysis, color mode gray scale, screen mode standard screen, data display combine 1.

\subsection{Sensory evaluation}

The raw material (tuna meat) and the extrudates with different corn starch contents $(20 \%, 25 \%, 30 \%, 35 \%$ and $40 \%$, w/w) were subjected to sensory evaluation, to assess the effect of extrusion cooking and corn starch contents on the acceptability of products. The acceptability to the aspects of texture, flavor and color were all determined.

The sensory panel consisted of 20persons ( 10 female/10 male; aged between 25 and 35 years). The assessors were previously trained in odor recognition, sensory evaluation techniques and had experience in sensory evaluation of meat products. The method of sensory assessment was according to Fang et al. (2017). The panelists cleared their nasal passage between samples by $1 \mathrm{~min}$ resting. The sensory descriptors were evaluated by a nine-point scale ( $1=$ "dislike extremely", 9="like extremely"). A score of 5 was considered as a neutral score, and the scores larger than 5 were in the "like" range.

\subsection{Statistical analysis}

Statistical significant differences between values were evaluated at $P<0.05$ level with a pairwise comparison tests using SPSS 21.0 (IBM SPSS Statistics).

\section{Results and discussion}

\subsection{Expansion ratio}

Effects of different corn starch contents on expansion ratio of the extrudates were shown in Table 1. The expansion ratio of the extrudates ranged from $1.17 \pm 0.04$ to $1.23 \pm 0.07$, and no significantly difference was observed between the extrudates ( $p>0.05)$. The expansion conditions (sleeve temperature, screw speed and feeder speed) and the properties of tuna meat were the same in this study. However, different corn starch contents seemed to have no influence on expansion ratio. The degree of expansion of the extrudate is related to the size, amount and distribution of the air surrounded by the cooked matrix (Yanniotis et al., 2007). The expansion ratio was closely related to moisture content (Beck et al., 2017; Singh et al., 2014), however the moisture content remained the same (30 wt\%) for each extrudate in the present study.

\subsection{Bulk density and hardness}

From Table 1, bulk density and hardness of the extrudates ranged from $0.84 \pm 0.06 \mathrm{~g} / \mathrm{mL}$ to $1.01 \pm 0.13 \mathrm{~g} / \mathrm{mL}$ and $41910 \pm 8988 \mathrm{~N}$ to $51834 \pm 8494 \mathrm{~N}$, respectively.

Statistical analyses showed that the bulk density displayed no significant changes among different corn starch contents $(p>0.05)$. It had been reported that the bulk density and porosity of extruded products were dependent on feed moisture content, residence time and temperature, which were fixed in our paper (Gopirajah \& Muthukumarappan, 2017; Thymi et al., 2005).

The hardness is the average force required for a probe to penetrate the extrudate. The same to expansion ratio, no significant difference was observed between the extrudates with different corn starch contents $(p>0.05)$. Previous study reported 
Table 1. Physicochemical properties of the extrudates with different corn starch contents.

\begin{tabular}{|c|c|c|c|c|c|c|}
\hline \multirow{2}{*}{\multicolumn{2}{|c|}{$\begin{array}{l}\text { Physicochemical } \\
\text { properties }\end{array}$}} & \multicolumn{5}{|c|}{ Corn starch contents } \\
\hline & & $20 \%$ & $25 \%$ & $30 \%$ & $35 \%$ & $40 \%$ \\
\hline \multicolumn{2}{|c|}{ Expansion ratio } & $1.18 \pm 0.04^{\mathrm{a}}$ & $1.17 \pm 0.04^{\mathrm{a}}$ & $1.18 \pm 0.03^{\mathrm{a}}$ & $1.23 \pm 0.07^{\mathrm{a}}$ & $1.20 \pm 0.03^{\mathrm{a}}$ \\
\hline \multicolumn{2}{|c|}{ Bulk density $(\mathrm{g} / \mathrm{mL})$} & $0.91 \pm 0.04^{\mathrm{a}}$ & $1.01 \pm 0.13^{\mathrm{a}}$ & $0.89 \pm 0.09^{\mathrm{a}}$ & $0.93 \pm 0.10^{\mathrm{a}}$ & $0.84 \pm 0.06^{\mathrm{a}}$ \\
\hline \multirow[t]{3}{*}{ Color } & $L^{*}$ & $46.99 \pm 3.49^{\mathrm{b}}$ & $46.91 \pm 3.39^{\mathrm{b}}$ & $44.78 \pm 3.60^{\mathrm{b}}$ & $40.25 \pm 4.69^{\mathrm{ab}}$ & $36.69 \pm 3.74^{\mathrm{a}}$ \\
\hline & $a^{*}$ & $8.02 \pm 0.75^{c}$ & $7.37 \pm 0.84^{\mathrm{c}}$ & $6.45 \pm 0.89^{b c}$ & $4.86 \pm 1.28^{\mathrm{ab}}$ & $3.52 \pm 1.11^{\mathrm{a}}$ \\
\hline & $b^{*}$ & $23.29 \pm 3.26^{c}$ & $20.94 \pm 2.66^{c}$ & $18.84 \pm 3.44^{b c}$ & $13.58 \pm 4.19^{\mathrm{ab}}$ & $9.78 \pm 3.27^{\mathrm{a}}$ \\
\hline \multicolumn{2}{|c|}{ Hardness $(\mathrm{N})$} & $41910 \pm 8988^{a}$ & $42651 \pm 9031^{a}$ & $51834 \pm 8494^{a}$ & $48136 \pm 9493^{\mathrm{a}}$ & $50895 \pm 6349^{a}$ \\
\hline \multicolumn{2}{|c|}{ PIVD (\%) } & $82.83 \pm 0.39^{\mathrm{a}}$ & $85.76 \pm 0.00^{\mathrm{b}}$ & $85.09 \pm 1.36^{\mathrm{b}}$ & $86.30 \pm 0.46^{\mathrm{b}}$ & $85.51 \pm 0.12^{\mathrm{b}}$ \\
\hline Crude pro & ntent (\%) & $76.44 \pm 1.44^{\mathrm{f}}$ & $67.65 \pm 1.95^{\text {bcde }}$ & $64.54 \pm 1.57^{\mathrm{abcd}}$ & $61.73 \pm 1.06^{\mathrm{ab}}$ & $59.84 \pm 1.51^{\mathrm{a}}$ \\
\hline
\end{tabular}

Values followed by the different letter in the same row (small letter) are significantly different $(p<0.05)$. $\mathrm{L}^{*}, \mathrm{a}^{*}$ and $\mathrm{b}^{*}$ mean the Lightness, redness/greenness and yellowness/blueness of products, respectively.

that the hardness of extrudate increased as the feed moisture content increased (Shraddha et al., 2017), which was controlled to $30 \mathrm{wt} \%$ in our study.

From what has been discussed above, it can be founded that the different corn starch contents were not the decisive factor on bulk density and hardness during extrusion cooking.

\subsection{Color and crude protein content}

Food color is one of the appearance indexes; which is one of the important qualities of external features, besides the crude protein content of food is the foundation and essential estimated index of nutritional value.

Table 1 reflected that the color ( $L^{*}, a^{*}$ and $b^{*}$ value) and crude protein content decreased with the increased corn starch contents, from $46.99 \pm 3.49$ to $36.69 \pm 3.74\left(L^{\star}\right), 8.02 \pm 0.75$ to $3.52 \pm 1.11\left(a^{*}\right)$, $23.29 \pm 3.26$ to $9.78 \pm 3.27\left(b^{*}\right)$ and $76.44 \pm 1.44 \%$ to $59.84 \pm 1.51 \%$ (crude protein content), respectively. While color $\left(L^{*}, a^{*}\right.$ and $b^{*}$ value) has no significant influence between adjacent corn starch contents ( $p>0.05)$, as evidenced by statistical results. It might be due to with the increase of corn starch content, the Maillard reaction would occur violently in sleeve between monosaccharide from polysaccharide decomposition and protein molecules from tuna meat. Another reason might be also due to the increased corn starch contents, which made the extrudates displayed the color closer to corn starch. Therefore, the color was a trend of slight decrease. On the other hand, decreased tuna meat content caused the drop of exturdates crude protein content because of higher protein content in tuna meat than the corn starch.

\subsection{PIVD}

At present, the research on protein digestibility methods mainly includes protein in vivo digestibility and protein in vitro digestibility. In general, the former is time consuming and needs more costs, while PIVD is relatively simple, fast method, and has good repeatability.

Protein denaturation and starch gelatinization are the main reactions occurred during extrusion cooking, by the combined effect of pressure, temperature and mechanical shear (Surasani, 2016). However, protein denaturation and starch gelatinization will improve the digestibility, resulting to the increase of PIVD. According to Boff Zortéa-Guidolin et al. (2017), the degrees of denaturation and gelatinization increased on account of suited increasing moisture content, feeder rate, screw speed and barrel temperature, but exceed high barrel temperature decreased protein digestibility contrarily.

In this study, the results showed that there was no significant difference of PIVD between different corn starch contents except $20 \mathrm{wt} \%$, which with the lowest PIVD of $82.83 \pm 0.39 \%$. The extrudate with the lowest content of corn starch (20 wt\%) meant the highest protein content, which would significantly reduce the denatured degree of protein due to the content of protein was too high under the same operating conditions, resulting to the lowest PIVD. However, the denatured degree did not reduce when the content of corn starch was larger than $20 \mathrm{wt} \%$. It was indicated that the denatured degree was similar if the content of protein was in a reasonable range.

\subsection{Thermal properties}

The denaturation temperature is used to describe the thermal stability of protein and it is one of the most important factors in food processing. Because protein denaturation can cause protein senior structure unfold and sequentially various food features reduced or lost significantly. Therefore, determination of food protein denaturation temperature has important guiding significance for protein application. DSC, a heat analysis method developed in the 1960s, has become an important tool in detection of protein denaturation temperature (He et al., 2013).

In this study, DSC was used to determine the thermal denaturation temperature of the extrudates. As presented in Figure 2, all the extrudates displayed prominent endothermic peaks, and the peak temperature is the denaturation temperature. The denaturation temperatures of extrudates with different corn starch contents $\left(20 \%, 25 \%, 30 \%, 35 \%\right.$ and $40 \%$, w/w) were $81.9^{\circ} \mathrm{C}$, $94.6^{\circ} \mathrm{C}, 99.4^{\circ} \mathrm{C}, 89.6^{\circ} \mathrm{C}$ and $84.9^{\circ} \mathrm{C}$, respectively.

As described above, starch gelatinization is one of main reactions during extrusion cooking. Starch gelatinization is a process of breaking down the hydrogen bonds in the presence of water and heat, further lead to the breakdown of starch grains and the formation of micellar network (Jafari et al., 
2017; Akande et al., 2017). The overall strength of the micellar network could influence the thermal stability of extrudates, which was dependent on the operational conditions. However, except starch gelatinization, degradation also occurred during extrusion cooking, not only the degradation of starch grains but also the degradation of gelatinized starch (Liu et al., 2017; Mitrus et al., 2017). The degradation of gelatinized starch would destroy the micellar network and reduce its strength.

According the results of DSC, the thermal stability of the extrudate with $30 \mathrm{wt} \%$ of corn starch content was the best, and it turned weaker no matter the content of corn starch increased or decreased. When the content of corn starch less than $30 \mathrm{wt} \%$, the less starch content lead to more degree of degradation, which lead to the weaker strength of micellar network. Therefore, the thermal stability reduced as the corn starch contents reduced from $30 \mathrm{wt} \%$ to $20 \mathrm{wt} \%$. However, the thermal stability also reduced when the content of corn starch more than $30 \mathrm{wt} \%$. The more content of corn starch meant the less content of protein, and the less content of protein resulted in the weaker thermal stability.

\subsection{Microstructure}

To explore the internal micro sturcture of the extrudates, the samples were subjected to SEM examination. From the micrographs, the integrated and distinct muscle fiber could be

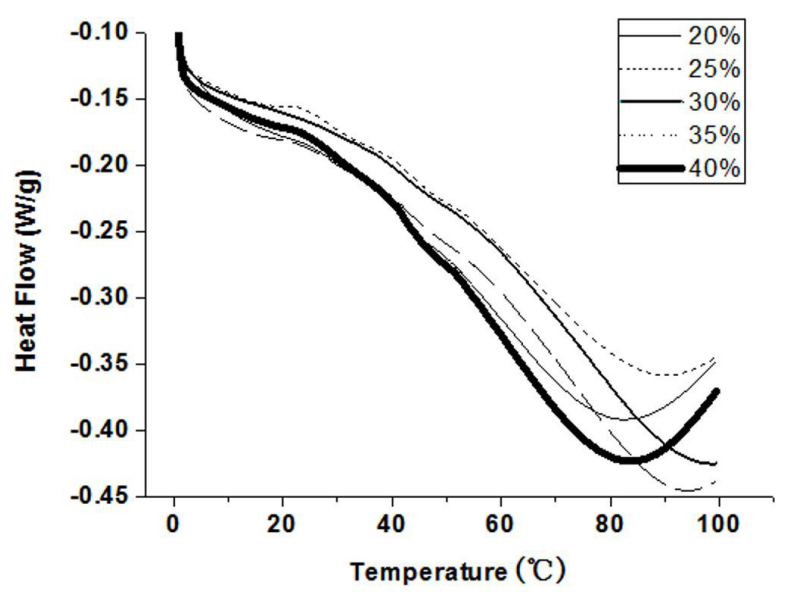

Figure 2. DSC of the extrudates of different corn starch contents. observed from Figure 3c. Besides, the micrograph of $30 \mathrm{wt} \%$ corn starch content was obviously smoother as compared with others, which indicated the corn starch grains were completely gelatinized.

As discussed above, the less starch content of corn starch lead to more degradation when the content less than $30 \mathrm{wt} \%$. The observed particulates in Figure 3(a) and (b) were due to the degradation of gelatinized starch, which broke the formed micellar network during extrusion. Besides, the fracture of muscle fiber was also obvious. However, the observed particulates in Figure 3(d) and (e) were due to the un-gelatinized corn starch particles adhered to the surface of muscle fiber, which suggested the incomplete gelatinization degree. It might be not conducive to the taste and acceptability of the extrudates by consumers (Omosebi et al., 2018).

In conclusion, the results of micrographs were in agreement with the results of DSC. $30 \mathrm{wt} \%$ of corn starch content was more suitable for the extrusion cooking of tuna meat, because the gelatinization degree was optimal under our operating conditions.

\subsection{Sensory evaluation}

The sensory assessment of the acceptability of each sample is shown in Table 2.

As shown in Table 2, the sensory scores of tuna meat on texture, flavor and color were $1.36 \pm 0.20,2.03 \pm 0.58$ and $3.61 \pm 0.91$, respectively, and the overall acceptability score was $2.34 \pm 1.14$. As described in introduction, the tuna meat with the disadvantages of dark, strong flavor and unacceptable textural properties, therefore the tuna meat were unacceptable to the sensory panel. Besides, the strong flavor mainly referred to fishy odor, this was because the tuna meat was rich in unsaturated fatty acids and the unsaturated fatty acids were readily oxidized to the volatile compounds with fishy odor (Fang et al., 2017). However, the texture, flavor and color were all improved after the treatment of extrusion cooking. The scores of the extrudates with different corn starch contents in all aspects were all larger than 5, which meant that they were all acceptable to the sensory panel. The improvement of texture, flavor and color were possibly due to the formation of micellar network and Maillard reaction during extrusion cooking (Cho \& Ryu, 2017).

Table 2. Sensory scores of raw material and the extrudates with different corn starch contents.

\begin{tabular}{|c|c|c|c|c|c|}
\hline \multirow{2}{*}{\multicolumn{2}{|c|}{ Samples }} & \multicolumn{3}{|c|}{ Acceptability } & \multirow{2}{*}{ Overall acceptability } \\
\hline & & Texture & Flavor & Color & \\
\hline \multicolumn{2}{|c|}{ Raw material (tuna meat) } & $1.36 \pm 0.20^{\mathrm{a}}$ & $2.03 \pm 0.58^{a}$ & $3.61 \pm 0.91^{\mathrm{a}}$ & $2.34 \pm 1.14^{\mathrm{a}}$ \\
\hline \multirow{5}{*}{$\begin{array}{c}\text { Extrudates with } \\
\text { different corn starch } \\
\text { contents }\end{array}$} & $20 \mathrm{wt} \%$ & $6.21 \pm 0.29^{b}$ & $6.39 \pm 0.24^{\mathrm{b}}$ & $7.54 \pm 0.33^{\mathrm{b}}$ & $6.71 \pm 0.66^{\mathrm{b}}$ \\
\hline & $25 \mathrm{wt} \%$ & $6.56 \pm 0.30^{c}$ & $6.24 \pm 0.54^{\mathrm{b}}$ & $7.29 \pm 0.43^{\mathrm{b}}$ & $6.69 \pm 0.71^{\mathrm{b}}$ \\
\hline & $30 \mathrm{wt} \%$ & $7.18 \pm 0.27^{\mathrm{d}}$ & $6.43 \pm 0.22^{\mathrm{b}}$ & $7.62 \pm 0.39^{b}$ & $7.08 \pm 0.58^{c}$ \\
\hline & $35 \mathrm{wt} \%$ & $6.50 \pm 0.54^{\mathrm{c}}$ & $6.11 \pm 0.50^{\mathrm{b}}$ & $7.39 \pm 0.27^{\mathrm{b}}$ & $6.67 \pm 0.70^{\mathrm{b}}$ \\
\hline & $40 \mathrm{wt} \%$ & $6.33 \pm 0.47^{\mathrm{bc}}$ & $6.28 \pm 0.25^{\mathrm{b}}$ & $7.48 \pm 0.30^{\mathrm{b}}$ & $6.70 \pm 0.66^{\mathrm{b}}$ \\
\hline
\end{tabular}

${ }^{\text {a-d }}$ Means within a column with different superscript letters differ significantly $(p<0.05)$. 


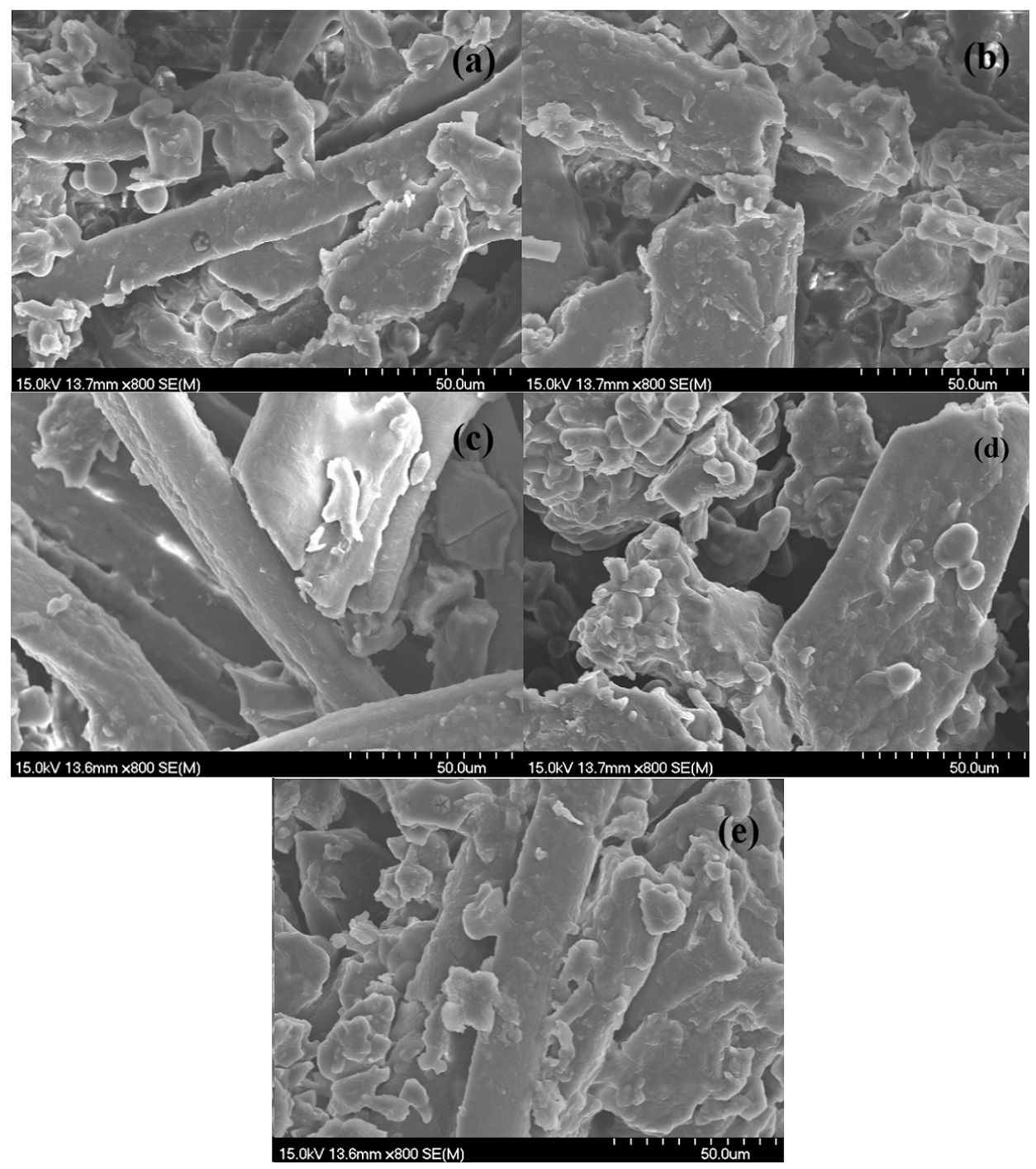

Figure 3. SEM of the extrudates with different corn starch contents of $20 \mathrm{wt} \%$ (a), $25 \mathrm{wt} \%$ (b), $30 \mathrm{wt} \%$ (c), $35 \mathrm{wt} \%$ (d) and $40 \mathrm{wt} \%$ (e).

Besides, no significant difference was observed between the extrudates with different corn starch contents in the aspects of flavor and color $(p>0.05)$, which indicated that the corn starch contents had no effect on the flavor and color of extrudate. However, the texture of the extrudates with different corn starch contents differed significantly. The extrudate with $30 \mathrm{wt} \%$ corn starch content was most satisfied by sensory panel, followed by $25 \mathrm{wt} \%, 35 \mathrm{wt} \%, 40 \mathrm{wt} \%$ and $20 \mathrm{wt} \%$. As discussed in 3.6, when the content of corn starch was too little, the degradation of gelatinized starch would be more serious, which would break the formed micellar network during extrusion. However, when the content of corn starch was too much, the un-gelatinized corn starch particles would be adhered to the surface of muscle fiber. Therefore, the extrudate with $30 \mathrm{wt} \%$ corn starch content was significant better than others in texture $(p<0.05)$.

Above all, the overall acceptability of the extrudate with $30 \mathrm{wt} \%$ corn starch content was significant better than others $(p<0.05)$, which also indicated that $30 \mathrm{wt} \%$ of corn starch content was more suitable for the extrusion cooking of tuna meat.

\section{Conclusion}

In this paper, the effect of extrusion cooking with different corn starch contents on the characteristics of tuna-based extrudates was studied. Expansion ratio, bulk density, color, hardness, protein in vitro digestibility, crude protein content, thermal properties and microstructure of the extrudates were measured. Besides, the acceptability of the extrudates was assessed by sensory evaluation.

The results showed that the corn starch contents had no effect on expansion ratio, bulk density and hardness of the extrudates. However, with the increase of corn starch content, the color of extrudate turned to darker, greener and yellower, which was mainly due to the more intense Maillard reaction and the color of corn starch. Besides, no significant difference was observed when the corn starch contents larger than $20 \mathrm{wt} \%$, which indicated the 
denatured degree was similar if the content of protein was in a reasonable range. According to the results of DSC, the thermal stability of the extrudate with $30 \mathrm{wt} \%$ of corn starch content was much better than others, which indicated that the strength of formed micellar network was the strongest. Besides, the results of micrographs were also in agreement with the results of DSC. Above all, the overall acceptability of the extrudate with $30 \mathrm{wt} \%$ corn starch content was significant better than others $(\mathrm{p}<0.05)$, which also indicated that $30 \mathrm{wt} \%$ of corn starch content was more suitable for the extrusion cooking of tuna meat.

\section{Acknowledgements}

This work was supported financially by the National Natural Science Foundation of China (No. 31301437), Natural Science Foundation of Zhejiang (No. LQ13C200003).

\section{References}

Akande, O. A., Nakimbugwe, D., \& Mukisa, I. M. (2017). Optimization of extrusion conditions for the production of instant grain amaranthbased porridge flour. Food Science \& Nutrition, 5(6), 1205-1214. http://dx.doi.org/10.1002/fsn3.513. PMid:29188049.

Altan, A., McCarthy, K. L., \& Maskan, M. (2008). Evaluation of snack foods from barley-tomato pomace blends by extrusion processing. Journal of Food Engineering, 84(2), 231-242. http://dx.doi.org/10.1016/j. jfoodeng.2007.05.014.

Anton, A. A., Gary Fulcher, R., \& Arntfield, S. D. (2009). Physical and nutritional impact of fortification of corn starch-based extruded snacks with common bean (Phaseolus vulgaris L.) flour: Effects of bean addition and extrusion cooking. Food Chemistry, 113(4), 989996. http://dx.doi.org/10.1016/j.foodchem.2008.08.050.

Beck, S. M., Knoerzer, K., \& Arcot, J. (2017). Effect of low moisture extrusion on a pea protein isolate's expansion, solubility, molecular weight distribution and secondary structure as determined by fourier transform infrared spectroscopy (FTIR). Journal of Food Engineering, 214, 166-174. http://dx.doi.org/10.1016/j.jfoodeng.2017.06.037.

Boff Zortéa-Guidolin, M. E., Piler de Carvalho, C. W., Bueno de Godoy, R. C., Mottin Demiate, I., \& Paula Scheer, A. (2017). Influence of extrusion cooking on in vitro digestibility, physical and sensory properties of brazilian pine seeds flour (araucaria angustifolia). Journal of Food Science, 82(4), 977-984. http://dx.doi.org/10.1111/17503841.13686. PMid:28339105.

Cho, S. Y., \& Ryu, G. H. (2017). Effects on quality characteristics of extruded meat analog by addition of tuna sawdust. Journal of the Korean Society of Food Science \& Nutrition, 46(4), 465-472. http:// dx.doi.org/10.3746/jkfn.2017.46.4.465.

De Cruz, C., Kamarudin, M., Saad, C., \& Ramezani-Fard, E. (2015). Effects of extruder die temperature on the physical properties of extruded fish pellets containing taro and broken rice starch. Animal Feed Science and Technology, 199, 137-145. http://dx.doi.org/10.1016/j. anifeedsci.2014.11.010.

Ding, Q.-B., Ainsworth, P., Plunkett, A., Tucker, G., \& Marson, H. (2006). The effect of extrusion conditions on the functional and physical properties of wheat-based expanded snacks. Journal of Food Engineering, 73(2), 142-148. http://dx.doi.org/10.1016/j. jfoodeng.2005.01.013.

Fang, Y., Gu, S., Zhang, J., Liu, S., Ding, Y., \& Liu, J. (2017). Deodorisation of fish oil by nanofiltration membrane process: focus on volatile flavour compounds and fatty acids composition. International
Journal of Food Science \& Technology, 53(3), 692-699. http://dx.doi. org/10.1111/ijfs.13644.

Gopirajah, R., \& Muthukumarappan, K. (2017). Effect of extrusion process conditions on the physical properties of tef-oat healthy snack extrudates. Journal of Food Processing and Preservation, 42(3), 1-9. http://d-x.doi.org/10.1111/jfpp.13559

He, X., Cao, W., Zhao, Z., \& Zhang, C. (2013). Analysis of protein composition and antioxidant activity of hydrolysates from Paphia undulate. Journal of Food and Nutrition Research, 1(3), 30-36.

Hirth, M., Leiter, A., Beck, S. M., \& Schuchmann, H. P. (2014). Effect of extrusion cooking process parameters on the retention of bilberry anthocyanins in starch based food. Journal of Food Engineering, 125, 139-146. http://dx.doi.org/10.1016/j.jfoodeng.2013.10.034.

Jafari, M., Koocheki, A., \& Milani, E. (2017). Effect of extrusion cooking on chemical structure, morphology, crystallinity and thermal properties of sorghum flour extrudates. Journal of Cereal Science, 75, 324-331. http://dx.doi.org/10.1016/j.jcs.2017.05.005.

Lakshmi Devi, N., Aparna, K., \& Kalpana, K. (2013). Utilization of fish mince in formulation and development of pasta products. International Food Research Journal, 20(1), 219-224.

Li, M., Hasjim, J., Xie, F., Halley, P. J., \& Gilbert, R. G. (2014). Shear degradation of molecular, crystalline, and granular structures of starch during extrusion. Stärke, 66(7-8), 595-605. http://dx.doi. org/10.1002/star.201300201.

Liu, Y., Chen, J., Luo, S., Li, C., Ye, J., Liu, C., \& Gilbert, R. (2017). Physicochemical and structural properties of pregelatinized starch prepared by improved extrusion cooking technology. Carbohydrate Polymers, 175, 265-272. http://dx.doi.org/10.1016/j.carbpol.2017.07.084. PMid:28917865.

Masatcioglu, T. M., Ng, P. K., \& Koksel, H. (2014). Effects of extrusion cooking conditions and chemical leavening agents on lysine loss as determined by furosine content in corn based extrudates. Journal of Cereal Science, 60(2), 276-281. http://dx.doi.org/10.1016/j. jcs.2014.06.008.

Mitrus, M., Wójtowicz, A., Oniszczuk, T., Gondek, E., \& Mościcki, L. (2017). Effect of processing conditions on microstructure and pasting properties of extrusion-cooked starches. International Journal of Food Engineering, 13(6), 112-118. http://dx.doi.org/10.1515/ijfe-2016-0287.

Moad, G. (2011). Chemical modification of starch by reactive extrusion. Progress in Polymer Science, 36(2), 218-237. http://dx.doi.org/10.1016/j. progpolymsci.2010.11.002.

Monsoor, M., \& Yusuf, H. (2002). In vitro protein digestibility of lathyrus pea (Lathyrus sativus), lentil (Lens culinaris), and chickpea (Cicer arietinum). International Journal of Food Science \& Technology, 37(1), 97-99. http://dx.doi.org/10.1046/j.1365-2621.2002.00539.x.

Moscicki, L., \& van Zuilichem, D. J. (2011). Extrusion-cooking and related technique. In: L. Moscicki, Extrusion-cooking techniques: applications, theory and sustainability (pp. 1-24). Weinheim: Wiley. http://dx.doi.org/10.1002/9783527634088.

Omosebi, M. O., Osundahunsi, O. F., \& Fagbemi, T. N. (2018). Effect of extrusion on protein quality, antinutritional factors, and digestibility of complementary diet from quality protein maize and soybean protein concentrate. Journal of Food Biochemistry, e12508. http:// dx.doi.org/10.1111/jfbc.12508.

Samuelsen, T. A., Mjøs, S. A., \& Oterhals, Å. (2013). Impact of variability in fishmeal physicochemical properties on the extrusion process, starch gelatinization and pellet durability and hardness. Animal Feed Science and Technology, 179(1), 77-84. http://dx.doi.org/10.1016/j. anifeedsci.2012.10.009. 
Samuelsen, T., Mjøs, S., \& Oterhals, Å. (2014). Influence of type of raw material on fishmeal physicochemical properties, the extrusion process, starch gelatinization and physical quality of fish feed. Aquaculture Nutrition, 20(4), 410-420. http://dx.doi.org/10.1111/anu.12093.

Shaviklo, G. R., Olafsdottir, A., Sveinsdottir, K., Thorkelsson, G., \& Rafipour, F. (2011). Quality characteristics and consumer acceptance of a high fish protein puffed corn-fish snack. Journal of Food Science and Technology, 48(6), 668-676. http://dx.doi.org/10.1007/s13197010-0191-1. PMid:23572803.

Shraddha, B., Mohan, S., \& Satyendra, T. (2017). Effect of process and machine parameters on physical properties of extrudate during extrusion cooking of rice, ashwagandha powder and spinach powder blends. International Journal of Chemical Studies, 5(6), 1657-1662.

Singh, R. K., Majumdar, R. K., \& Venkateshwarlu, G. (2014). Optimum extrusion-cooking conditions for improving physical properties of fish-cereal based snacks by response surface methodology. Journal of Food Science and Technology, 51(9), 1827-1836. http://dx.doi. org/10.1007/s13197-012-0725-9. PMid:25190837.

Stojceska, V., Ainsworth, P., Plunkett, A., \& İbanoğlu, Ş. (2009). The effect of extrusion cooking using different water feed rates on the quality of ready-to-eat snacks made from food by-products. Food Chemistry, 114(1), 226-232. http://dx.doi.org/10.1016/j.foodchem.2008.09.043.

Surasani, V. K. R. (2016). Application of food extrusion process to develop fish meat-based extruded products. Food Engineering Reviews, 8(4), 448-456. http://dx.doi.org/10.1007/s12393-016-9148-0.
Suseno, S. H. (2015). Proximate, Fatty Acid, Amino Acid and Mineral Composition of Tuna (Thunnus sp.) By-Product from West Sumatra Province, Indonesia. Pakistan Journal of Nutrition, 14(1), 62-66. http://dx.doi.org/10.3923/pjn.2015.62.66.

Thymi, S., Krokida, M., Pappa, A., Maroulis, Z. (2005). Structural properties of extruded corn starch. Journal of food engineering, 68(4), 519-526.http://dx.doi.org/10.1016/j.jfoodeng.2004.07.002.

Tiwari, A., \& Jha, S. (2017). Extrusion Cooking Technology: Principal Mechanism and Effecect on Direct Expanded Snacks - An Overview. International Journal of Food Studies, 6(1), 113-128. http://dx.doi. org/10.7455/ijfs/6.1.2017.a10.

Tumuluru, J. S., Sokhansanj, S., Bandyopadhyay, S., \& Bawa, A. (2013). Changes in moisture, protein, and fat content of fish and rice flour coextrudates during single-screw extrusion cooking. Food and Bioprocess Technology, 6(2), 403-415. http://dx.doi.org/10.1007/ s11947-011-0764-7.

Yanniotis, S., Petraki, A., \& Soumpasi, E. (2007). Effect of pectin and wheat fibers on quality attributes of extruded cornstarch. Journal of Food Engineering, 80(2), 594-599. http://dx.doi.org/10.1016/j. jfoodeng.2006.06.018.

Yu, L., Ramaswamy, H. S., \& Boye, J. (2012). Twin-screw extrusion of corn flour and soy protein isolate (SPI) blends: a response surface analysis. Food and Bioprocess Technology, 5(2), 485-497. http:// dx.doi.org/10.1007/s11947-009-0294-8. 